\title{
A gyógyfürdőellátások igénybevételi mutatói Magyarországon
}

\author{
Varga Veronika ${ }^{1}$ - Boncz Imre dr. ${ }^{1}$ - Sebestyén Andor dr. ${ }^{1}$ \\ Endrei Dóra dr. ${ }^{1}$ - Ágoston István dr. $^{1}$ - Péter Iván dr. ${ }^{1,2}$ - Molics Bálint dr. ${ }^{3}$ \\ ${ }^{1}$ Pécsi Tudományegyetem, Egészségtudományi Kar, Egészségbiztosítási Intézet, Pécs \\ ${ }^{2}$ Zsigmondy Vilmos Harkányi Gyógyfürdőkórház, Harkány \\ ${ }^{3}$ Pécsi Tudományegyetem, Egészségtudományi Kar, Fizioterápiás és Sporttudományi Intézet, Pécs
}

\begin{abstract}
Bevezetés: A gyógyfürdőellátások helye az egészségügyi ellátásban jól meghatározott és jelentősen növekedett, a megvalósuló kezelések igénybevételi mutatói azonban kevésbé ismertek.

Célkitüzés: Tanulmányunk célja a hazai gyógyfürdőintézmények egészségbiztosító által közfinanszírozott egészségügyi ellátásokra vonatkozó igénybevételi és egészségbiztosítási mutatóinak elemzése.

Adatok és módszerek: Az elemzéshez felhasznált adatok a Nemzeti Egészségbiztosítási Alapkezelő finanszírozási adatbázisából származnak. A vizsgált időszak a 2009 és 2016 közötti éveket öleli fel. Elemzésünkben vizsgáltuk a gyógyfürdőellátások kezelési számait, a társadalombiztosítási kiadásokat, az igénybevételek területi egyenlőtlenségeit és a kezelések számának nemenkénti és korcsoportonkénti megoszlását.

Eredmények: A kezelések száma 2009-ben volt a legnagyobb 7349587 kezeléssel, míg az azt követő években ez fokozatosan csökkent - 2012-ben 6558204 kezelés történt. A 'Gyógyvizes gyógymedence' ellátás volt minden évben a leggyakoribb ellátási forma, melynek előfordulása azonban csökkenő tendenciát mutat az évek alatt - 2009-ben 2544 617, 2016-ban 1898338 kezelést végeztek. A legmagasabb társadalombiztosítási támogatás 2016-ban fordult elő 4,261 milliárd forinttal. Az előző években alacsonyabb kiadást láttunk: 2010-ben 3,928 milliárd Ft, 2011-ben 3,921 milliárd Ft és 2012-ben 3,875 milliárd Ft. 2016-ban az igénybevétel Csongrád megyében mutatja a legnagyobb előfordulást 13 714/10 000 lakos kezeléssel, és 8160 eFt/10 000 lakos társadalombiztosítási támogatással, míg a legalacsonyabb Nógrád megyében található 3233/10 000 lakos kezeléssel és 2192 eFt/10 000 lakos társadalombiztosítási támogatással. A lakosság, valamint a nemek korcsoportjainak bontásában is a 60-69 éves korcsoportban a legmagasabb az igénybevétel.

Következtetés: A gyógyfürdőkben társadalombiztosítási finanszírozással megvalósuló ellátások igénybevételében az évek alatt jelentős változás országosan nem következett be, azonban nemek, korcsoportok és megyék szerinti bontásban érdemi területi eltérések mutatkoznak.
\end{abstract}

Orv Hetil. 160(Suppl 1): 22-28.

Kulcsszavak: gyógyfürdőellátások, egészségbiztosítás, finanszírozás, igénybevétel

\section{Utilization indicators of balneotherapy in Hungary}

Introduction: The role of spa therapy is well defined and its importance has significantly increased in the healthcare but the utilization indicators of the implemented treatments are less known.

Aim: The objective of our study was to analyze the utilization and the social insurance indicators of the healthcare publicly financed by health insurance in spa institutions.

Data and methods: The data used for the analysis were derived from the funding database of the National Health Insurance Fund of Hungary. The period examined covered the years between 2009 and 2016. The spa treatment counts, social insurance expenses, the territorial inequalities in utilization, sex and age distribution of the treatments were examined.

Results: The treatment counts were the highest (7 349 587) in 2009 and they gradually decreased with 6558204 treatments by 2012. 'Spa pool of medicinal water' treatment was the most common care in each year which incidence showed a downward trend during the past years: 2544617 treatments were performed in 2009 but 2016 showed only 1898338 treatments. We found the highest health insurance expenditures in 2016:4.261 billion HUF or 13.8 EUR. In the previous years, there was a lower health insurance expenditure: in 20103.928 billion HUF (14.3 million EUR), in 20113.921 billion HUF (14.0 million EUR) and in 20123.875 billion HUF (13.4 million EUR). The utilization made the highest incidence of treatments in Csongrád county with 13 174/10 000 inhabitants and 
8160 thousand HUF/10 000 inhabitants of social security subsidy in 2016 . The lowest utilization counts for treatments were found in Nógrád county with 3233/10 000 inhabitants and 2192 thousand HUF/10 000 inhabitants of social security subsidy. The highest utilization indicators were found in the age group between 60 and 69 in the distribution of population and genders.

Conclusion: In the utilization of spa therapy funded by health insurance fund, no significant change has occurred during the past years but territorial discrepancies can be seen in sex, age, and county breakdown.

Keywords: spa therapy, health insurance, funding, utilization

Varga V, Boncz I, Sebestyén A, Endrei D, Ágoston I, Péter I, Molics B. [Utilization indicators of balneotherapy in Hungary]. Orv Hetil. 2019; 160(Suppl 1): 22-28.

A fürdőkhöz köthető gyógyító tevékenységek sok európai országban az egészségügyi rendszer szerves részét képezik. Az adott országokban a helyi, természetes gyógyító erőforrások mindig is tárgyát jelentették és jelentik még ma is a tudományos kutatásoknak. A kutatásokban a gyógyfürdő́khöz köthetố tevékenységek révén a betegségek kezelései megfigyelésre kerülnek, az eredmények függvényében pedig azok jóváhagyottá és ajánlhatóvá válhatnak [1].

A balneoterápia a hazai és a nemzetközi szakirodalomban is széles körben kutatott és publikált terület, melyben a terápia hatásossága megerősítést kap kiemelten ízületi gyulladásos és kopásos megbetegedések tüneteinek enyhítésében [2-7], bőrproblémák kezelésében [8, 9], a derékfájás panaszainak mérséklésében [10-12], valamint keringési rendellenességek javításában is [13-15].

A gyógyfürdőellátások kiemelt jelentőséggel bírnak az egészségturisztikai programkínálat bővítésében is. A hazai gyógyfürdők meghatározó szereplői az egészségturisztikai piacnak, jelentős külföldi betegforgalmat látnak el. Ugyanakkor komoly problémát okoznak a gyógyfürdőellátások hatásosságára vonatkozó tudományos evidenciák limitációi [16-19]. Bender és mtsai hiánypótló munkájukban metaanalízis keretében mutatták be a magyar gyógyfürdőellátások hatásosságának klinikai bizonyítékait [20].

Az egészségügyi ellátások eredményességén túl azonban nélkülözhetetlen a kezelésekkel kapcsolatos további szempontok szerint történő elemzések elvégzése is a még célzottabb, hatékonyabb és gazdaságosabb ellátások megtervezéséhez, majd azok eléréséhez. Hazánkban a társadalombiztosítási finanszírozással igénybe vehető gyógyfürdő- és egyéb gyógyászati ellátások orvosi rehabilitációjában csak az előírtak szerint múködő, az Egészségügyi Minisztérium által kiadott rendeletnek megfelelő gyógyintézmények vehetnek részt, melyeknek meghatározottak az elvárt szakmai, infrastrukturális, személyzeti és minőségi követelményeik is [21]. Az ezen gyógyfürdőkben megvalósuló eljárások igénybevételi és egészségbiztosítási mutatói azonban kevésbé publikáltak.

Tanulmányunk célja a hazai gyógyfürdőellátásokat nyújtó intézmények társadalombiztosító által közfinanszírozott egészségügyi ellátásokra vonatkozó igénybevételi és egészségbiztosítási mutatóinak elemzése.

\section{Adatok és módszerek}

Az elemzéshez felhasznált adatok a Nemzeti Egészségbiztosítási Alapkezelő (korábban Országos Egészségbiztosítási Pénztár) finanszírozási adatbázisából származnak. Az adatbázis tartalmazza valamennyi, közfinanszírozásban részesülő, gyógyfürdőellátásokat nyújtó intézmények által végzett egészségügyi ellátás adatait. A gyógyfürdőellátásokat „Az orvosi rehabilitáció céljából társadalombiztosítási támogatással igénybe vehető gyógyászati ellátásokról” szóló 5/2004. (XI. 19.) EüM rendelet alapján azonosítottuk. A vizsgált időszak a 2009 és 2016 közötti éveket öleli fel.

Az elemzés első lépésében a 8 évet átfogó időszak közfinanszírozott kezelési számait határoztuk meg. A kezeléseket ellátási formánként bontottuk le. Az ellátásformák az 5/2004. (XI. 19.) EüM rendeletben meghatározott 11 kezelési típust tartalmazzák (1. ábra, l. táblázat). Meghatároztuk a különböző ellátási formák megoszlását, illetve ezek változását a vizsgált 8 évben (2. ábra).

Vizsgáltuk továbbá a kezelésekre fordított társadalombiztosítási kiadásokat, jogcímenként. A gyógyfürdőellátások teljes éves társadalombiztosítási támogatása, valamint az azon belüli közgyógyellátásnak, az üzemi baleseteknek és a foglalkozási megbetegedéseknek a támogatási költségei kerültek meghatározásra a 2009 és 2016 közötti időszakban (2. táblázat).

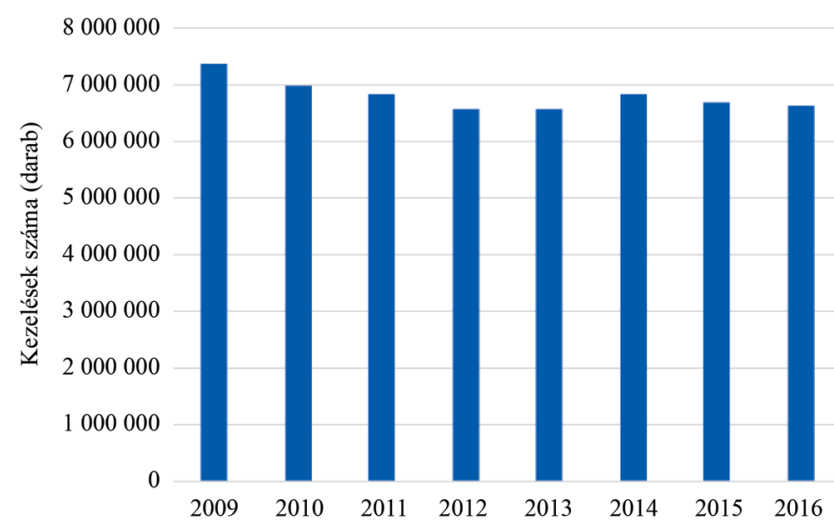

1. ábra $\quad$ Az éves kezelések száma a társadalombiztosítás által támogatott gyógyfürdőellátásokban (2009-2016) 
1. táblázat |A társadalombiztosítás által támogatott gyógyfürdőellátások éves kezelésszámai ellátási típusonként (2009-2016)

\begin{tabular}{|c|c|c|c|c|c|c|c|c|}
\hline Az ellátás formája & 2009 & 2010 & 2011 & 2012 & 2013 & 2014 & 2015 & 2016 \\
\hline Gyógyvizes gyógymedence & 2544617 & 2344694 & 2255680 & 2108371 & 2048262 & 2076148 & 1979780 & 1898338 \\
\hline Orvosi gyógymasszázs & 1972957 & 1828822 & 1746512 & 1601505 & 1587316 & 1642037 & 1601668 & 1590565 \\
\hline $\begin{array}{l}\text { Víz alatti csoportos } \\
\text { gyógytorna }\end{array}$ & 638148 & 612920 & 609717 & 596949 & 619421 & 686773 & 673278 & 700479 \\
\hline Víz alatti vízsugármasszázs & 588944 & 563716 & 544579 & 520005 & 516678 & 521369 & 507700 & 500868 \\
\hline $\begin{array}{l}18 \text { éves kor alatti csoportos } \\
\text { gyógyúszás }\end{array}$ & 565368 & 586517 & 584623 & 602343 & 609142 & 630696 & 606164 & 581557 \\
\hline Iszappakolás & 482595 & 487800 & 513010 & 521358 & 543720 & 597683 & 588415 & 592235 \\
\hline Súlyfürdő & 236551 & 218823 & 225891 & 230012 & 252810 & 282810 & 293634 & 316277 \\
\hline $\begin{array}{l}\text { Komplex fürdőgyógyászati } \\
\text { ellátás }\end{array}$ & 228001 & 230346 & 263813 & 273275 & 272799 & 279065 & 291125 & 317407 \\
\hline Szénsavas fürdő & 82711 & 85319 & 93121 & 90819 & 94441 & 96073 & 100384 & 97781 \\
\hline Gyógyvizes kádfürdő & 9695 & 8480 & 7169 & 6559 & 8513 & 8013 & 9038 & 8878 \\
\hline Szén-dioxid-gyógygázfürdő & & & & 7008 & 16996 & 18879 & 22021 & 20400 \\
\hline Összesen & 7349587 & 6967437 & 6844115 & 6558204 & 6570098 & 6839546 & 6673207 & 6624785 \\
\hline
\end{tabular}

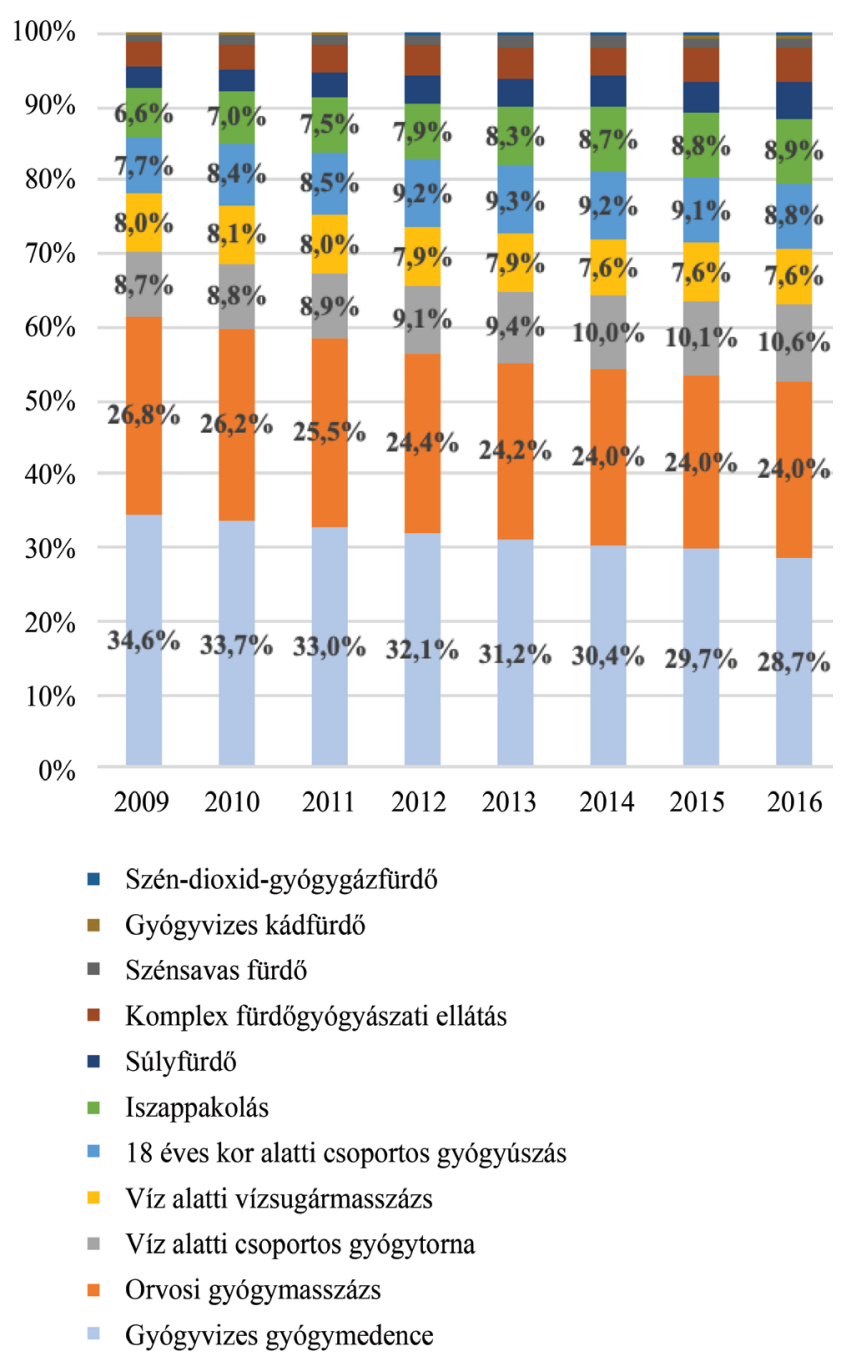

2. ábra $\quad$ A társadalombiztosítás által támogatott gyógyfürdőellátások éves kezelésszámainak megoszlása ellátási típusonként (20092016)
Ezt követően a gyógyfürdős ellátások igénybevételének területi egyenlőtlenségeit elemeztük. A szolgáltatásokhoz történő hozzáférés indikátoraként a 10000 lakosra vetített kezelésszámot határoztuk meg megyei bontásban (3. ábra). A finanszírozási egyenlőtlenségeket a kezelések társadalombiztosítási támogatásának 10000 lakosra vetített összegével elemeztük (4.ábra). A 10000 lakosra vetített adatok közlésénél az egyes megyék népességszámára vonatkozó adatok a Központi Statisztikai Hivatal interneten elérhető adataiból származnak [22]. A területi egyenlótlenségek elemzésekor minden esetben a kezelést igénybe vevő személy állandó lakcímét használtuk, és nem a kezelést végző gyógyfürdő székhelyét.

Végezetül a gyógyfürdő- és egyéb gyógyászati ellátási kezelések számát nemenként és korcsoportonként elemeztük (5. ábra).

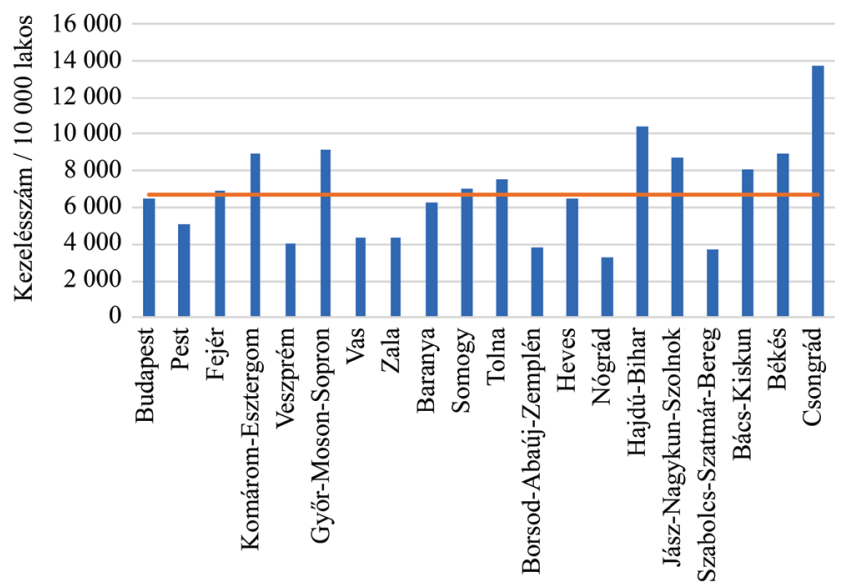

3. ábra $\mid$ A gyógyfürdő- és egyéb gyógyászati ellátások 10000 lakosra vetített éves kezelésszámai megyei bontásban (2016) 


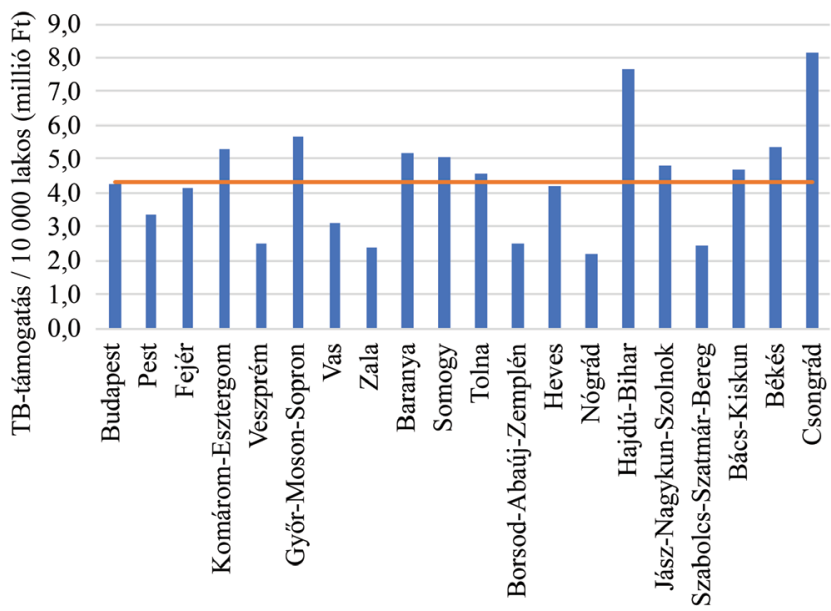

4. ábra

A gyógyfürdő- és egyéb gyógyászati ellátások 10000 lakosra vetített éves társadalombiztosítási támogatása megyei bontásban (2016)

A magyar egészségügyi rendszer felépítését, múködését [23-28], erőforrás-gazdálkodási [29-34] és adatvédelmi [35-39] kérdéseit a szakirodalom részletesen tárgyalja.

\section{Eredmények}

A 2009 és 2016 közötti vizsgált időszakban a hazai gyógyfürdőkben elvégzett, társadalombiztosítás által támogatott kezelések számát az 1 . ábra szemlélteti. A gyógyfürdőkben támogatott kezelések száma 2009-ben volt a legnagyobb 7349587 kezeléssel, a további években 7 millió feletti kezelés nem fordult elő. A 2009-et követó években a kezelések száma fokozatosan csökkenve 2012-ben érte el a legalacsonyabb kezelési számot 6558204 kezeléssel. Vizsgált időszakunk utolsó évében a kezelések száma 6624785 volt.

A gyógyfürdőkben nyújtott 11 ellátás közül a kezelések számának vonatkozásában minden évben a 'Gyógyvizes gyógymedence' ellátás volt a leggyakoribb ellátási forma (1. táblázat). Ez az ellátás a kezelések számát nézve 8 év vizsgálatában azonban csökkenő tendenciát mutat - 2009-ben volt a legtöbb ilyen jellegű kezelés (2 544 617), míg 2016-ban a legkevesebb (1 898338 ).

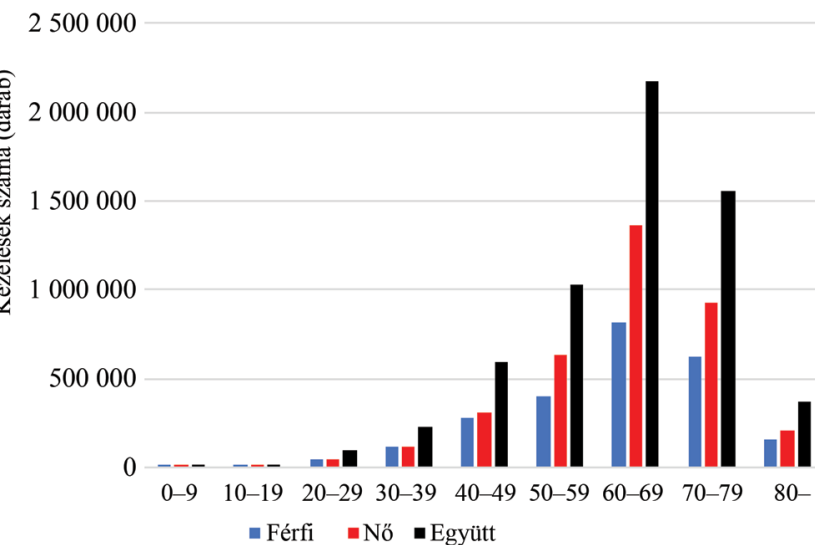

5. ábra A gyógyfürdő- és egyéb gyógyászati ellátások kezelésszáma nemenként és korcsoportonként (2016)

Valamennyi vizsgált évben a 2. leggyakoribb ellátási forma az 'Orvosi gyógymasszázs' volt. Az 'Orvosi gyógymasszázs' kezelések száma 2009-ben 1972957 volt, ami folyamatosan csökkenve a legalacsonyabb értékét 2013-ban mutatja 1587316 kezeléssel. A 2016. év kezeléseinek száma - 1590565 - további érdemi eltérést nem mutat a 2013. évhez viszonyítva.

A 2009 és 2016 közötti évek mindegyikében a 3. leggyakoribb ellátás a 'Víz alatti csoportos gyógytorna' volt, a 4. a '18 éves kor alatti csoportos gyógyúszás', az 5. pedig a 'Víz alatti vízsugármasszázs'. Sorrendbeli különbség csak 2009-ben volt megfigyelhető, amikor a 'Víz alatti vízsugármasszázs' gyakoribb megjelenést mutatott, mint a '18 éves kor alatti csoportos gyógyúszás'.

A kezelésszámban az alacsonyabb ellátási formák mint az 'Iszappakolás', a 'Súlyfürdő', a 'Komplex fürdőgyógyászati ellátás' és a 'Szénsavas fürdő' - azonban évról évre egyre nagyobb előfordulást mutatnak. A legkevésbé alkalmazott ellátási forma valamennyi vizsgált évben a 'Gyógyvizes kádfürdő' volt, ez egyik évben sem haladta meg a 10000 kezelést.

A különböző ellátási formák megoszlását a vizsgált 8 évben a 2. ábra szemlélteti. A 'Gyógyvizes gyógymedence' ellátás részesedése a 2009. évi 34,6\%-ról 2016-ban 28,7\%-ra csökkent. Az 'Orvosi gyógymasszázs' ellátás részesedése szintén csökkent 26,8\%-ról (2009) 24\%-ra (2016).

2. táblázat |A gyógyfürdőellátások éves társadalombiztosítási támogatása (2009-2016, millió Ft)

\begin{tabular}{|c|c|c|c|c|c|c|c|c|}
\hline Megnevezés & 2009 & 2010 & 2011 & 2012 & 2013 & 2014 & 2015 & 2016 \\
\hline Normatív támogatás & 3728 & 3611 & 3612 & 3570 & 3803 & 4105 & 4084 & 4126 \\
\hline Közgyógyellátás & 164 & 160 & 160 & 154 & 150 & 141 & 132 & 121 \\
\hline $\begin{array}{l}\text { Üzemi balesetek és foglalkozási megbetegedések } \\
\text { gyógykezelésének támogatása }\end{array}$ & 8 & 10 & 10 & 10 & 11 & 12 & 13 & 14 \\
\hline A támogatás áfatartalma & 137 & 146 & 140 & 140 & 143 & & & \\
\hline Összesen & 4037 & 3927 & 3922 & 3874 & 4107 & 4258 & 4229 & 4261 \\
\hline
\end{tabular}

áfa = általános forgalmi adó 
A gyógyfürdőkben megvalósult ellátások társadalombiztosítási támogatására valamennyi évben közel 4 milliárd forintot fordított a Nemzeti Egészségbiztosítási Alapkezelő (2. táblázat). A támogatás csak 2010-ben, 2011-ben és 2012-ben maradt el a 4 milliárd forinttól 3927 millió Ft, 3922 millió Ft, 3874 millió Ft. A legmagasabb támogatás vizsgált időszakunk utolsó évében, 2016-ban fordult elő 4261 millió forinttal. A közgyógyellátás támogatása 8 év alatt folyamatosan csökkent - 164 millió forintról 121 millió forintra, míg az üzemi balesetek és a foglalkozási megbetegedések támogatása folyamatosan emelkedett -8 millió forintról 14 millió forintra.

A gyógyfürdőellátások kezelésszámmal mért igénybevételi mutatói 2016-ban megyei bontásban 10000 lakosra vetítve Csongrád megyében mutatják magasan a legnagyobb előfordulást 13714 kezeléssel (3. ábra). A további sorrendben Hajdú-Bihar megye 10477 kezelés/10 000 lakos értékkel a 2., míg Győr-Moson-Sopron megye 9181 kezelés/10 000 lakos értékkel a 3. legnagyobb kezelésszámot mutató megye. A 10000 lakosra jutó legalacsonyabb megyei kezelésszám Nógrád megyében 3233 kezeléssel, Szabolcs-Szatmár-Bereg megyében 3739 kezeléssel és Borsod-Abaúj-Zemplén megyében 3820 kezeléssel fordul elő. A legmagasabb és a legalacsonyabb igénybevétel között $13714 / 3233=4,2$-szeres eltérést találtunk.

A gyógyfürdőellátások kezeléseinek 10000 lakosra vetített társadalombiztosítási támogatása Csongrád (8160 eFt), Hajdú-Bihar (7639 eFt) és Győr-Moson-Sopron (5649 eFt) megyében a legmagasabb (4. ábra).

A 10000 lakosra jutó legalacsonyabb társadalombiztosítási támogatást Nógrád $(2192 \mathrm{eFt})$, Zala $(2380 \mathrm{eFt})$ és Szabolcs-Szatmár-Bereg (2463 eFt) megyében találtuk. A legmagasabb és a legalacsonyabb ártámogatási mutató között 8160/2192 = 3,7-szeres eltérést találtunk.

A gyógyfürdőellátások igénybevétele a lakosság korcsoportos bontásában folyamatos emelkedést mutat a 60-69 éves korcsoportig (5. ábra). Az azt követő 70-79 éves korcsoportban ismét csökken az igénybevétel. A férfi és női kezelésszámok a 39. életévig közel azonosak. A 40. életév feletti korcsoportokban a női nem kezelésszámai minden korcsoportban magasabbak, mint a férfineméi.

\section{Megbeszélés}

Az egészségügyi rendszerben az egészségügyi ellátások igénybevételi mutatói már gazdagon ismertetésre kerültek a hazai és a nemzetközi irodalomban is. Az egészségügyi ellátásokat követő gondozási, rehabilitációs ellátások igénybevétele azonban a hazai irodalom vonatkozásában kevésbé ismert. Tanulmányunk céljául így a hazai gyógyfürdőellátások igénybevételi mutatóinak meghatározását tüztük ki.
A gyógyfürdőellátások kezelésszámai a vizsgált nyolcéves időszakunkban enyhe csökkenést mutattak, míg az ellátások éves társadalombiztosítási támogatásában ez idő alatt közel 5\%-os emelkedés volt megfigyelhető. A társadalombiztosítási támogatáson belül míg a normatív támogatás megközelítőleg 10\%-kal, az üzemi balesetek és foglalkozási megbetegedések támogatása megközelítőleg 75\%-kal nőtt, addig a közgyógyellátás költségei 35\%-kal csökkentek.

A gyógyfürdő-szolgáltatások közül a legnagyobb kezelésszámban előforduló ellátás minden évben a 'Gyógyvizes gyógymedence' és az 'Orvosi gyógymasszázs' volt, melyek kezelésszámai azonban az évek alatt csökkenő tendenciát mutatnak. A kisebb kezelésszámú ellátások mint az 'Iszappakolás', a 'Súlyfürdő', a 'Komplex fürdőgyógyászati ellátás' és a 'Szénsavas fürdő' - azonban évről évre egyre gyakoribb megjelenéssel fordulnak elő a gyógyfürdőkben. A komplex fürdőgyógyászati ellátás 4-féle ellátásból tevődik össze, így ezen komplex ellátás emelkedése összefügghet a 'Gyógyvizes gyógymedence' és az 'Orvosi gyógymasszázs' ellátások számának csökkenésével, amennyiben ezeket a komplex ellátás keretében írják fel.

A megyei bontásban vizsgált területi egyenlőtlenségek elemzésekor lényeges különbségek mutatkoztak mind a kezelések számának, mind pedig a társadalombiztosítási támogatásnak a vonatkozásában. A területi egyenlőtlenségek okainak elemzése további kutatás tárgyát képezheti.

Míg Magyarországon széles körben elfogadott a gyógyfürdőellátások társadalombiztosítási támogatása, Oroszországban komoly gondot okoz az ehhez szükséges közösségi források biztosítása [40]. Romániában az országos gyógyfürdőfejlesztési stratégia keretében szintén kulcskérdés a finanszírozási forma meghatározása (közösségi vagy magánfinanszírozás) [41].

Géher kiváló tanulmányban dolgozta fel a fizioterápiás ellátások egészségbiztosítási vonatkozásait. Megállapította, hogy a gyógyfürdőellátások finanszírozása 2006ban érte el a legmagasabb összeget (5,1 milliárd Ft), ezt követően csökkent. A gyógyfürdőkben magas előfordulást mutató masszázs más egészségügyi ellátási formában is gyakori kezelésnek számít. A járóbeteg-ellátásban a különböző fizioterápiás ellátások kezelésszámainak vonatkozásában a leggyakoribb balneoterápiás kezelésként a masszázs jelent meg (1 046177 kezelés) 2009-ben [42].

A hazai gyógyfürdők kémiailag változatos összetételű vizeinek kihasználásából adódóan egyértelmű, hogy a gyógyvizes gyógymedencei kezelés a legnagyobb számban igénybe vett kezelés a gyógyfürdők ellátási formái közül. A gyakorlatban megvalósuló kezelések kiválasztásának alapja a megfelelő indikáció, mely kezeléseket a megfelelő paraméterekkel, megfelelő kivitelezéssel alkalmazva lehet folytatni [43].

A különböző balneoterápiás kezelések hatékonyságát alátámasztó munkák további gazdagítása indokolt, mely- 
lyel a kezeléseknek nagyobb és szélesebb körü elfogadása vívható ki. A gyakorlatban az eredményes és hatékony kezelések kiválasztásához, majd alkalmazásához pedig nélkülözhetetlenek a terápiákat elméleti oldalról bemutató munkák is $[44,45]$.

A gyógyfürdőellátások egyre nagyobb szerepet töltenek be a népegészségügyi szempontból is jelentős kórképek rehabilitációjában, a betegek életminőségének helyreállításában [46-49].

Tanulmányunk limitációi között első helyen kell megemlítenünk, hogy elemzésünkben csak a társadalombiztosítási támogatásra vonatkozó adatokat elemeztük. A magánforrásokra vonatkozó adatokkal nem rendelkezünk, holott ezek elemzése jelentősen bővítené ismereteinket a gyógyfürdőellátások igénybevételi mutatóiról.

A hazai gyógyfürdő-szolgáltatást nyújtó intézmények kezeléseinek igénybevételét megismerve a szolgáltatók javíthatják a felkészültségüket a betegellátás minőségének fejlesztése érdekében.

Anyagi támogatás: A közlemény a Magyar Nemzeti Bank Pallas Athéné Innovációs és Geopolitikai Alapítványának (PAIGEO) támogatásával készült, „A pénzbeli és természetbeni ellátások arányai az Egészségbiztositási Alap költségvetésében a munkaeröpiaci folyamatok tükrében” címü projekt keretében.

Szerzôi munkamegosztás: A vizsgálat tervezése és lefolytatása: V. V., B. I., S. A., E. D., Á. I., P. I., M. B. Statisztikai elemzések: V. V., B. I., M. B. Irodalomkutatás: V. V., P. I., S. A., E. D., Á. I., M. B. A kézirat megszövegezése: V. V., B. I., S. A., E. D., Á. I., P. I., M. B. A cikk végleges változatát valamennyi szerző elolvasta és jóváhagyta.

Érdekeltségek: A szerzőknek nincsenek érdekeltségeik.

\section{Irodalom}

[1] World Health Organization. The WHO strategy on research for health. In: The WHO strategy on research for health. WHO Library Cataloguing-in-Publication Data, Geneva, 2012; pp. 14-33.

[2] Verhagen AP, Bierma-Zeinstra SM, Boers M, et al. Balneotherapy (or spa therapy) for rheumatoid arthritis. Cochrane Database Syst Rev. 2015; 4: CD000518.

[3] Bálint GP, Buchanan WW, Ádám A, et al. The effect of the thermal mineral water of Nagybaracska on patients with knee joint osteoarthritis - a double blind study. Clin Rheumatol. 2007; 26: 890-894.

[4] Tékus V, Borbély É, Kiss T, et al. Investigation of lake Hévíz mineral water balneotherapy and Hévíz mud treatment in murine osteoarthritis and rheumatoid arthritis models. Evid Based Complement Alternat Med. 2018; 2018: 4816905.

[5] Karagülle M, Kardeş S, Diş̧̧i R, et al. Spa therapy adjunct to pharmacotherapy is beneficial in rheumatoid arthritis: a crossover randomized controlled trial. Int J Biometeorol. 2018; 62: 195205.

[6] Hanzel A, Horvát K, Molics B, et al. Clinical improvement of patients with osteoarthritis using thermal mineral water at
Szigetvár Spa - results of a randomised double-blind controlled study. Int J Biometeorol. 2018; 62: 253-259.

[7] Kovács C, Pecze M, Tihanyi Á, et al. The effect of sulphurous water in patients with osteoarthritis of hand. Double-blind, randomized, controlled follow-up study. Clin Rheumatol. 2012; 31 : 1437-1442.

[8] Huang A, Seité S, Adar T. The use of balneotherapy in dermatology. Clin Dermatol. 2018; 36: 363-368.

[9] Péter I, Jagicza A, Ajtay Z, et al. Balneotherapy in psoriasis rehabilitation. In Vivo 2017; 31: 1163-1168.

[10] Tefner IK, Németh A, Lászlófi A, et al. The effect of spa therapy in chronic low back pain: a randomized controlled, single-blind, follow-up study. Rheumatol Int. 2012; 32: 3163-3169.

[11] Kulisch A, Bender T, Németh A, et al. Effect of thermal water and adjunctive electrotherapy on chronic low back pain: a double-blind, randomized, follow-up study. J Rehabil Med. 2009; 41: 73-79.

[12] Pittler MH, Karagülle MZ, Karagülle M, et al. Spa therapy and balneotherapy for treating low back pain: meta-analysis of randomized trials. Rheumatology (Oxford) 2006; 45: 880-884.

[13] Oláh M, Koncz Á, Fehér J, et al. The effect of balneotherapy on antioxidant, inflammatory, and metabolic indices in patients with cardiovascular risk factors (hypertension and obesity) - a randomised, controlled, follow-up study. Contemp Clin Trials 2011; 32: 793-801.

[14] Pagourelias ED, Zorou PG, Tsaligopoulos M, et al. Carbon dioxide balneotherapy and cardiovascular disease. Int J Biometeorol. 2011; 55: 657-663.

[15] Fabry R, Monnet P, Schmidt J, et al. Clinical and microcirculatory effects of transcutaneous $\mathrm{CO}_{2}$ therapy in intermittent claudication. Randomized double-blind clinical trial with a parallel design. Vasa 2009; 38: 213-224.

[16] Bender T. Evidence based outcomes of balneotherapy. [Evidencián alapuló eredmények a balneoterápiában.] Orvostovábbk Szle. 2017; 24: 72-77. [Hungarian]

[17] Bender T, Bálint G, Prohászka Z, et al. The state of balneology in Hungary. Evidences on the effectiveness of Hungarian thermal waters. [A balneológia helyzete Magyarországon. Bizonyítékok a magyar gyógyvizek hatékonyságáról.] Magy Tud. 2013; 174: 1307-1311. [Hungarian]

[18] Varjú C, Kutas R, Pethő E, et al. Role of physiotherapy in the rehabilitation of patients with idiopathic inflammatory myopathies. [A fizioterápia szerepe az idiopathiás gyulladásos myopathiás betegek rehabilitációjában.] Orv Hetil. 2004; 145: 2530. [Hungarian]

[19] Bender T. Evidence-based physiotherapy. [Bizonyítékon alapuló fizioterápia.] Orv Hetil. 2013; 154: 1893-1899. [Hungarian]

[20] Bender T, Bálint G, Prohászka Z, et al. Evidence-based hydroand balneotherapy in Hungary - a systematic review and metaanalysis. Int J Biometeorol. 2014; 58: 311-323.

[21] 5/2004. (XI. 19.) EüM decree on health care services for medical rehabilitation available with social security subsidy. [5/2004. (XI. 19.) EüM rendelet az orvosi rehabilitáció céljából társadalombiztosítási támogatással igénybe vehető gyógyászati ellátásokról. 2. számú melléklet.] Hatályos jogszabályok gyưjteménye, Wolters Kluwer, Budapest. Available from: https:// net.jogtar.hu/jogszabaly?docid=A0400005.EUM [accessed: August 25, 2018. [Hungarian]

[22] Hungarian Central Statistical Office. Population by gender in 2001-2018. [Központi Statisztikai Hivatal (KSH). STADAT, A lakónépesség nemek szerint 2001-2018.] Available from: http://www.ksh.hu/stadat_eves_6_1 [accessed: July 17, 2018]. [Hungarian]

[23] Kovács G. Introduction to the health care system. In: Kovács G, Nogel M, Fáskerty É. Health and social rights. [Az egészségügyi ellátórendszer alapjai. In: Kovács G, Nogel M, Fáskerty É. Egészségügyi és szociális jog.] Universitas-Győr Nonprofit Kft., Győr, 2017; pp. 120-133. [Hungarian] 
[24] Endrei D, Molics B, Agoston I. Multicriteria decision analysis in the reimbursement of new medical technologies: real-world experiences from Hungary. Value Health 2014; 17: 487-489.

[25] Boncz I, Vajda R, Ágoston I, et al. Changes in the health status of the population of Central and Eastern European countries between 1990 and 2010. Eur J Health Econ. 2014; 15(Suppl 1): S137-S141.

[26] Boncz I, Nagy J, Sebestyén A, et al. Financing of health care services in Hungary. Eur J Health Econ. 2004; 5: 252-258.

[27] Boncz I, Evetovits T, Dózsa C, et al. The Hungarian Care Managing Organization Pilot Program. Value Health Reg Issues $2015 ; 7: 27-33$

[28] Greenberg D, Mohamed Ibrahim MIB, Boncz I. What are the challenges in conducting cost-of-illness studies? Value Health Reg Issues 2014; 4: 115-116.

[29] Endrei D, Zemplényi A, Molics B, et al. The effect of performance-volume limit on the DRG based acute care hospital financing in Hungary. Health Policy 2014; 115: 152-156.

[30] Boncz I, Kaló Z, Mohamed Ibrahim MIB, et al. Further steps in the development of pharmacoeconomics, outcomes research, and health technology assessment in Central and Eastern Europe, Western Asia, and Africa. Value Health Reg Issues 2013; 2: 169-170.

[31] Kovács G. Professional requirements for health care services. In: Kovács G, Nogel M, Fáskerty É. Health and social rights. [Az egészségügyi szolgáltatások szakmai követelményei. In: Kovács G, Nogel M, Fáskerty É. Egészségügyi és szociális jog.] Universitas-Győr Nonprofit Kft., Győr, 2017; pp. 134-137. [Hungarian]

[32] Boncz I, Sebestyén A. Financial deficits in the health services of the UK and Hungary. Lancet 2006; 368: 917-918.

[33] Boncz I, Dózsa C, Kaló Z, et al. Development of health economics in Hungary between 1990-2006. Eur J Health Econ. 2006; 7(Suppl 1): S4-S6.

[34] Boncz I, Nagy J, Körösi L, et al. The effect of the introduction of visit fee on the number of patient-visits to outpatient care departments in Hungary. Value Health 2008; 11: A368-A369.

[35] Kovács G. Data protection on health care: the outline of health care data management. [Adatvédelem az egészségügyben: az egészségügyi adatkezelés vázlata.] Med et Jur. 2011; 2(1): 1618. [Hungarian]

[36] Kovács G. Sectorial data protection: health care data protection. [Szektorális adatvédelem: egészségügyi adatvédelem.] Med et Jur. 2011; 2(2): 17-19. [Hungarian]

[37] Kovács G. Special issues in health care data protection. [Speciális területek az egészségügyi adatkezelésben.] Med et Jur. 2011; 2(3): 14-17. [Hungarian]

[38] Kovács G, Nogel M. Activity of forensic experts and quality assurance in Hungary. Forensic Sci Int. 2017; 277: 257-258.
[39] Gellérné Lukács É, Gyeney L, Kovács G, et al. Third-country nationals in the Hungarian public health care sector. New Med. 2015; 19: 29-36.

[40] Artem'eva GB, Gekht IA. Certain medico-economic prerequisites for the integration of spa and resort facilities into the system of compulsory health insurance. Vopr Kurortol Fizioter Lech Fiz Kult. 2013; 1: 83-85. [Russian]

[41] Surdu O, Surdu TV, Surdu M. State of art of balneotherapy/ thermalisme in Romania. Balneo Research J. 2015; 6: 86-91.

[42] Géher P. Physiotherapy from the view of health insurance financing. [A fizioterápia az egészségbiztosítás szemszögéből.] Orv Hetil. 2013; 154: 1917-1923. [Hungarian]

[43] Bálint G, Bálint P. The use of physiotherapy tools in medical treatment. The use of heat, light, electric, magnetic, ultrasound and shock wave therapy as well as medical massage in Hungarian medical practice. [A fizikoterápia eszköztárának felhasználása a gyógyításban. Hő, fény-, elektromos, mágneses, ultrahang- és lökéshullám-kezelés, valamint az orvosi masszázs alkalmazása a hazai klinikai gyakorlatban.] Orv Hetil. 2013; 154: 1905-1911. [Hungarian]

[44] Gömör B. The changing position of balneo- and hydrotherapy in medicine. [A balneo-, hidroterápia helyének változása a medicinában.] Orv Hetil. 2013; 154: 1900-1904. [Hungarian]

[45] Fehérné Kiss A. The importance of physiotherapeutic exercises in the treatment of different disorders. [A gyógytorna jelentősége a különböző betegségek kezelésében.] Orv Hetil. 2013; 154: 1912-1916. [Hungarian]

[46] Apor P. Cardiac rehabilitation and its sporty face. [A szívbetegek rehabilitációjának sportos arca.] Orv Hetil. 2018; 159: 13461352. [Hungarian]

[47] Müller A, Balatoni I, Csernoch L, et al. Quality of life of asthmatic patients after complex rehabilitation treatment. [Asztmás betegek életminőségének változása komplex rehabilitációs kezelés után.] Orv Hetil. 2018; 159: 1103-1112. [Hungarian]

[48] Sallai JR, Hunka A, Héjj G, et al. Helping reintegration of patients suffering from chronic musculoskeletal diseases with decreased working ability in the National Institute of Rheumatology and Physiotherapy, Budapest, Hungary. [Csökkent munkaképességú krónikus mozgásszervi betegek reintegrációjának elősegítése.] Orv Hetil. 2017; 158: 662-667. [Hungarian]

[49] Poór AK, Sárdy M, Cserni T, et al. Assessment of health-related quality of life in psoriasis patients in Hungary. [Psoriasisban szenvedő betegek életminőségének vizsgálata Magyarországon.] Orv Hetil. 2018; 159: 837-846. [Hungarian]

(Molics Bálint dr., Pécs, Rét u. 4., 7623 e-mail: molics.balint@etk.pte.hu) 